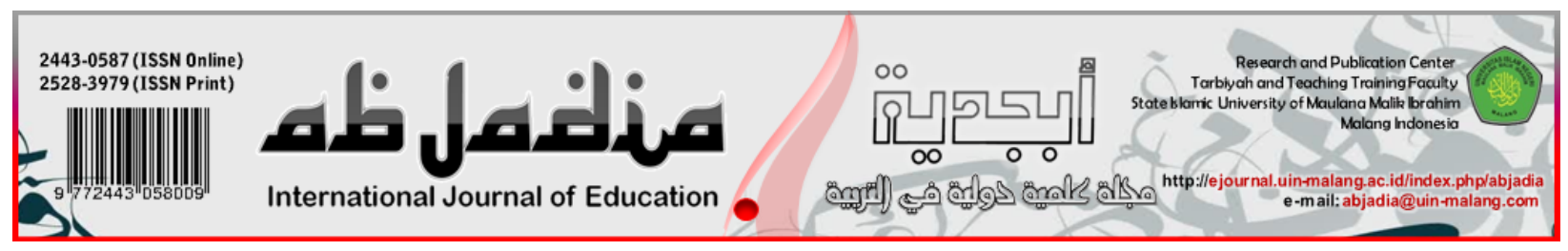

\title{
INTERACTIVE MULTIMEDIA IN INQUIRY LEARNING: ANALYZING POPULATION DYNAMICS FOR CRITICAL THINKING
}

\author{
Lia Umi Amaliya, Yuswanti Ariani Wirahayu, Alfyananda Kurnia Putra \\ Departement of Geography, Universitas Negeri Malang, Indonesia
}

Article History:

Received : 2021-07-02

Revised : 2021-11-29

Accepted : 2021-12-08

Published : 2021-12-26

\section{Keywords:}

Interactive Multimedia, Inquiry

Learning, Critical Thinking

*Correspondence Address:

liaumiaaml@gmail.com

\begin{abstract}
Inquiry learning is learning that requires students to be active and independent. Inquiry-based learning was developed for critical teaching and learning to students. Critical thinking skills that need to be developed in students, because it provides an understanding of a problem in a material and to be able to make decisions in everyday life. This study aimed to determine the effect of an android-based interactive multimedia-assisted inquiry learning model on students' critical thinking skills. This research is a quasiexperimental research with posttest only control group design. The research subject is SMA Brawijaya Smart School Malang, with class XI IPS 5 as the experimental class and XI IPS 6 as the control class. The instrument used is an essay test with indicators of critical thinking skills. The data analysis technique used is the independent sample t-test. The results showed that interactive multimedia-assisted inquiry learning based on Android affected essential thinking skills in the population dynamics material. This is evidenced by the average value of the experimental class with inquiry learning which has a higher value of 81,07 compared to the control class with the conventional model, which is 76,34 .
\end{abstract}

\section{(C) Introduction}

Technology and information in the 21st century are experiencing developments that affect education. These changes affect the development of the learning paradigm, which requires students to be able to collaborate, communicate, be creative, think critically, solve problems, information literacy, digital literacy, and the ability of science and technology (Kivunja 2014; Silber-Varod, Eshet-Alkalai, and Geri 2019). The shift in the current learning system is from teacher-centered to student center, combining knowledge and technology, and conducting distance learning (Riyana 2011; Yusuf and Al-Banawi 2013).

One of the demands of the 21st-century learning paradigm is that students can think critically. The ability to think critically is a basic competency that is expected to be possessed by students through educational activities (Adeyemi 2012). Critical thinking ability is high-level thinking that includes analyzing, processing information, and being able to solve problems to produce a decision (Haghparast, Nasaruddin, and Abdullah 2014; Setyowati, Sari, and Habibah 2020; Ulger 2016). Thinking skills are important for students to understand problems in material and be able to make decisions in everyday life. 
Students need to be trained early to have critical thinking skills. A good learning process is being able to educate students to have knowledge obtained from the material being studied (Sutiani, Situmorang, and Silalahi 2021) and facilitate to have ability scientific literacy and critical thinking skills (Auerbach and Schussler 2017). However, the reality on the ground, critical thinking skills have not been realized in learning activities. The teacher still explains the material conventionally using a lecture model with the question and answer method (Dia et al. 2021). One of the learning models that can improve students' critical thinking skills is inquiry learning.

Inquiry-based learning was developed to teach the way of thinking for students, especially critical thinking. Inquiry learning is learning to emphasize activeness in students through planning, investigating, obtaining information, and communicating the results or solutions related to an event (Duran and Dökme 2016; Palupi et al. 2020; Rodríguez et al. 2019; Sutiani et al. 2021). Inquiry learning emphasizes the process of seeking and finding answers independently for students.

Inquiry learning has advantages and disadvantages. The advantages are investigation-based activities so that they can produce findings from experimental activities (Gormally, Sullivan, and Szeinbaum 2016; Jeffery et al. 2016), developing aspects of knowledge and skills in students (Khalaf and Zin 2018), and learning through valuable experiences (Kaiser, Mayer, and Malai 2018). While the drawbacks are that students must be able to carry out investigative activities, require a long time, and there are long stages in learning activities (Khalaf and Zin 2018).

One of the weaknesses of inquiry learning in learning activities is that it takes a long time. So the solution that can be used is to add the use of media in learning activities. The use of learning media is very important as a component of supporting the achievement of learning objectives. One of the media that can be used is interactive multimedia based on android.

The use of these media as a solution to deliver complete learning in a short time. The use of digital learning media can also support the competencies and abilities of students in industry 4.0 (Putra et al. 2021). Android-based interactive multimedia is a media that combines various sources of information ranging from text, images, audio, video, animation, and others about a concept that can be accessed using a smartphone (Prabowo et al. 2016; Sophia and Yensasnidar 2019). Android-based interactive multimedia makes it easier for teachers and students to be able to access learning resources at any time and anywhere and learning are not monotonous with just text. Learning by utilizing visual elements can construct abstract knowledge so that it can provide easy understanding (Ma'ruf, Setiawan, and Suhandi 2019) and can activate several senses (sight, hearing, and others) in learning activities (Sophia and Yensasnidar 2019).

The material used in this media is the matter of Problems Caused by Population Dynamics. The population dynamics material is material that has a fairly broad scope. 
The material requires innovation and integration of text, images, audio, and video so that it can be easy to understand properly by students. Inquiry learning by utilizing Androidbased interactive multimedia as a technology-based media so that it can provide convenience in learning.

\section{[Q] Method}

\section{Design Research}

This research is a quasi-experimental research with a design research posttest only control group design. There are two groups in the study, namely the experimental class and the control class. The experimental class was given treatment using inquiry learning assisted by interactive multimedia based on android, while the control class was in the form of conventional learning assisted by interactive multimedia based on android.

\section{Research Subject}

The research subjects were students of class XI Social Sciences even semester subjects of Geography at SMA Brawijaya Smart School for the academic year 2020/2021. the class that was chosen as the experimental class and the control class was chosen randomly because there were only two class XI IPS. The class chosen as the experimental class is XI IPS 5 and the control class is XI IPS 6.

\section{Data Collection Procedure}

The data collection technique used in this study was in the form of an essay test to measure students' critical thinking skills. The research instrument uses a written test question with Higher Order of Thinking Skill (HOTS) and is in accordance with the indicators of critical thinking ability. Based on the research design, the posttest was given to the experimental class after receiving treatment, while the control class was given without any treatment. Before the test was carried out, the instrument was tested first to measure the validity and reliability.

\section{Data Analysis Techniques}

Data analysis was carried out with two tests, namely prerequisite tests and hypothesis tests. Test the prerequisites done before testing the hypothesis. The prerequisite test includes the normality test and homogeneity test. The normality test used the K-S test (Kolmogorov-Smirnov) through the SPSS 22.0 for Windows program with a 95\% confidence level. Meanwhile, the homogeneity test used Levine's test for the equation of variance. Furthermore, hypothesis testing using t-test for unpaired samples (independent sample t-test).

\section{Result}

The data presented are the results of research obtained from the experimental class and the control class. The research was carried out in the even semester of February 2021. 
The research was carried out in three meetings and was carried out online. The experimental class is class XI IPS 5 which is treated with an inquiry learning model. Meanwhile, class XI IPS 6 only uses conventional models in the form of lectures, discussions, and assignments.

The following data is a comparison of students' critical thinking skills in the experimental class and the control class. Test using essay questions as many as 10 questions that were carried out after the learning activities. The experimental class obtained an average critical thinking ability test score of 81.07 while the control class was 76.34. The following are the results of the distribution of the final data on the ability to think critically of students in the experimental class and control class.

Table 1. Distribution of Critical Thinking Frequency of Students in Experiment Class and Control Class

\begin{tabular}{|c|c|c|c|c|c|c|}
\hline \multirow[b]{2}{*}{ Classification } & \multirow[b]{2}{*}{ Value } & \multirow[b]{2}{*}{ Qualification } & \multicolumn{2}{|c|}{ Frequency } & \multicolumn{2}{|c|}{ Percentage } \\
\hline & & & Experiment & Control & Experiment & Control \\
\hline$A$ & $86-100$ & Very Good & 9 & 4 & 31 & 13,8 \\
\hline B & $71-85$ & Good & 16 & 20 & 55,2 & 69 \\
\hline C & $56-70$ & Pretty Good & 4 & 5 & 13,8 & 17,2 \\
\hline D & $41-55$ & Not Good & 0 & 0 & 0 & 0 \\
\hline $\mathrm{E}$ & $26-40$ & Very less & 0 & 0 & 0 & 0 \\
\hline \multicolumn{3}{|c|}{ Amount } & 29 & 29 & 100 & 100 \\
\hline
\end{tabular}

Source: Primary Data Analysis (2021)

Based on the picture above, the scores of the experimental class and control class students are divided into three classifications, namely Good, Very Good, and Fairly Good. Most of the test result scores are in the Good qualification, but the number with the Very Good qualification is more in the experimental class. Meanwhile, in the control class, the number of students classified as Good and Fairly Good is more than in the experimental class. This shows that students with critical thinking skills in the experimental class are higher than those in the control class. The difference in the frequency distribution in the experimental class and control class and described in the image as follows.

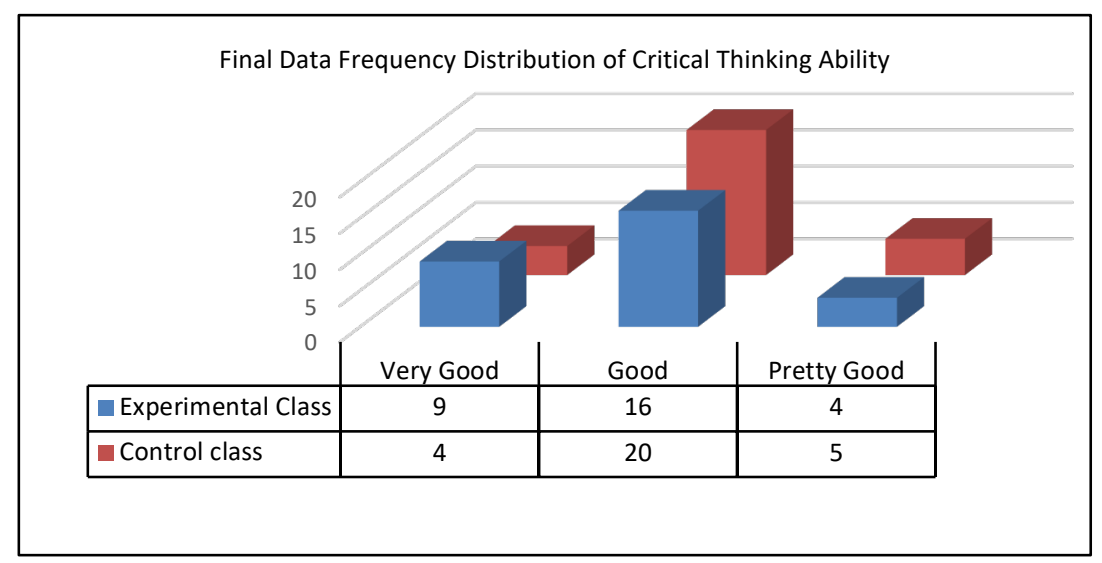

Figure 1. Graph of Students' Critical Thinking Ability in Experiment Class and Critical Class 


\section{jiscussion}

The success of inquiry learning on students' critical thinking skills is also related to the advantages possessed by inquiry learning. These advantages include: 1) students are more active in learning activities and 2) students can produce a discovery that comes from observation activities. In line with the advantages of inquiry learning according to Gormally et al (2016) and Jeffery et al (2016). The following is a description of the advantages of inquiry learning that affect students' critical thinking skills.

The first advantage is that students are more active in learning activities. The activeness of these students can simultaneously train each indicator in critical thinking skills starting from formulating problems, giving arguments, doing deduction/induction, evaluating, to being able to decide and implement. Each syntax in inquiry learning can develop students' critical thinking skills (Kahlke and Eva 2018). This is appropriate, that inquiry learning provides opportunities for students to be actively involved and can train critical thinking in solving scientific problems (Beck, Butler, and da Silva 2014).

The second advantage is that students can produce a discovery that comes from observation activities. Inquiry learning is basically a learning model that requires students to conduct independent investigations (Arsal 2017). With various stages in the model, students make observations related to the topic being studied. Students also conduct discussions to analyze the problems studied. Then at the stage of concluding conclusions, students can produce a good discovery regarding problem-solving and making appropriate decisions on the topics studied in their investigations. This is in line with the characteristics ability to think critically as a mental process that involves a high level of thinking in problem-solving and decision making (Al-mubaid 2014).

The effect of inquiry learning on critical thinking skills is shown during the learning activities. This is evidenced by learning activities based on 6 inquiry learning syntaxes. The syntax includes: 1) orientation, 2) formulating problems, 3) formulating hypotheses, 4) collecting data, 5) testing hypotheses, and 6) drawing conclusions. inquiry learning syntax is carried out in stages according to step by step in this order. In addition, there is influence is also inseparable from the indicators that are met. These indicators are used as a reference to measure the level of critical thinking skills of students. Where each indicator of critical thinking skills trained every syntax in inquiry learning is because they have a correlation with each other (Hadi, Susantini, and Agustini 2018). This makes the average value of students' critical thinking skills in the experimental class higher than the control class.

Inquiry learning in the implementation of research also found problems faced. The problem is related to the weakness of the model itself. One of the weaknesses of inquiry 
learning in its implementation is that it takes a long time to implement. In line with one of the weaknesses of inquiry learning according to Khalaf and Zin (2018). This weakness is due to the limited time for school learning when learning online. This makes the guidance provided less than optimal during student discussion activities. Based on the research that has been done, the weaknesses of the model can be minimized by allowing give students to study outside the relevant learning hours related to the stages of conducting an investigation.

The role of android-based interactive multimedia can also affect the success of the implementation of inquiry learning. The use of this media can be an advantage or a weakness in research activities. The advantages are as a form of integrating technology in study activities (Montrieux et al. 2015) as an innovation in improving learning. In addition, it can create learning that is more interesting and easy to understand using visual and audio media (Sophia and Yensasnidar 2019). Meanwhile, the weakness of using this media is that it can only be accessed via android.

Based on the research conducted, that by using inquiry learning on population dynamics material can make students of class XI IPS SMA Brawijaya Smart School able to learn actively and independently. This is realized by being able to carry out each stage in inquiry learning well, starting from activities to formulate problems, collect data, conduct data, to be able to solve problems that are in accordance with these problems. In addition, it trains students to understand and be able to express their opinions in discussion activities both with group members and with teachers.

This research is also inseparable from the obstacles experienced during the implementation of research in the field. The obstacle that has a big enough influence is due to the current Covid-19 condition, causing learning to be carried out online. Less than optimal learning due to the reduced amount of time in each subject compared to face-toface learning activities. One of the obstacles that learning is carried out remotely is the limited learning time so that the material delivered is not optimal (Nengrum, Pettasolong, and Nuriman 2021). In addition, there is a cut in learning time because teachers and students must enter the online learning application (zoom) before carrying out learning activities, this can occur due to signal conditions or technical errors.

The implementation of online learning also causes learning activities to be less than optimal in students' understanding. Understanding related to the material presented and the research activities carried out. Lack of understanding of students due to limited communication interactions (Pustika 2020) both with teachers and peers (Adnan and Anwar 2020). Because it is done online, then the test of critical thinking skills uses google form. The use of google forms can have an impact on students' lack of understanding in understanding the knowledge provided and causes some students to collect tests after past the deadline.

The uniqueness of this research is with the inquiry learning model utilizing interactive multimedia applications based on Android as a technology-based learning 
media. This can be used to change the way students learn to be modern and can take advantage of learning anytime and anywhere, especially right now when implementing online learning. Besides that, it can create interesting and easy understand learning for students.

\section{谓 Conclusion}

Based on the findings from the research result, that android-based interactive multimedia-assisted inquiry learning has an effect on students' critical thinking skills on population dynamics. This is evidenced by the hypothesis test using the t-test, that the significance is 0.018 . This is because in learning inquiry, students are invited to think critically to find answers independently based on the problems that have been formulated in each group.

Based on this, there are several suggestions given as follows: 1) Geography teachers are advised to use inquiry in learning activities; 2) Teachers need to make good plans and guide students during inquiry learning activities; 3) Schools can recommend teachers to use models that require students to be more active; and 4) The next researcher can combine inquiry learning with the help of media that is in accordance with the material and need understand the characteristics in the stages of inquiry learning.

\section{Bibliography}

Adeyemi, Sunday Bankole, "Developing Critical Thinking Skills in Students: A

Mandate for Higher Education in Nigeria", European Journal of Educational Research, 1 (2012), 155-161

Adnan, Muhammad, and Kainat Anwar, "Online Learning amid the COVID-19

Pandemic: Students' Perspectives", Journal of Pedagogical Sociology and Psychology, 2 (2020), 45-51

Al-mubaid, Hisham, "A New Method for Promoting Critical Thinking in Online Education." International Journal of Advanced Corporate Learning, 7 (2014), 34-37

Arsal, Zeki, "The Impact of Inquiry-Based Learning on the Critical Thinking Dispositions of Pre-Service Science Teachers", International Journal of Science Education, 39 (2017), 1326-1338

Auerbach, Anna Jo, and Elisabeth E. Schussler, "Curriculum Alignment with Vision and Change Improves Student Scientific Literacy", CBE Life Sciences Education, 16 (2017), 1-9

Beck, Christopher, Amy Butler, and Karen Burke da Silva,“Promoting Inquiry-Based 
Teaching in Laboratory Courses: Are Wemeeting the Grade?", CBE Life Sciences Education, 13 (2014) 444-452

Dia, Fitri, Amana Turohmah, Alfyananda Kurnia Putra, Yusuf Suharto, and East Java, "Improving Critical Thinking Ability : Earthcomm Learning For Watershed Conservation Materials", IJIS Edu : Indonesian Journal of Integrated Science Education, 3 (2021), 99-106

Duran, Meltem, and Ilbilge Dökme, “The Effect of the Inquiry-Based Learning Approach on Student's Critical-Thinking Skills", Eurasia Journal of Mathematics, Science and Technology Education, 12 (2016) 2887-2908

Gormally, Cara, Carol Subiño Sullivan, and Nadia Szeinbaum, “Uncovering Barriers to Teaching Assistants (TAs) Implementing Inquiry Teaching: Inconsistent Facilitation Techniques, Student Resistance, and Reluctance to Share Control over Learning with Students", Journal of Microbiology \& Biology Education, 17 (2016) 215224

Hadi, S. A., E. Susantini, and R. Agustini, “Training of Students' Critical Thinking Skills through the Implementation of a Modified Free Inquiry Model", Journal of Physics: Conference Series, 947 (2018)

Haghparast, Mahboobeh, Fariza Hanum Nasaruddin, and Noorhidawati Abdullah, "Cultivating Critical Thinking Through E-Learning Environment and Tools: A Review", Procedia - Social and Behavioral Sciences, 129 (2014)

Jeffery, Erica, Kathy Nomme, Thomas Deane, Carol Pollock, and Gülnur Birol, "Investigating the Role of an Inquiry-Based Biology Lab Course on Student Attitudes and Views toward Science", CBE Life Sciences Education, 15 (2016), 1-12

Kahlke, Renate, and Kevin Eva, "Constructing Critical Thinking in Health Professional Education", Perspectives on Medical Education, 7 (2018), 156-165

Kaiser, Irina, Jürgen Mayer, and Dumitru Malai, "Self-Generation in the Context of Inquiry-Based Learning", Frontiers in Psychology, 9 (2018), 1-16

Khalaf, Bilal Khalid, and Zuhana Bt Mohammed Zin, “Traditional and Inquiry-Based Learning Pedagogy: A Systematic Critical Review", International Journal of Instruction, 11 (2018), 545-564

Kivunja, Charles, "Do You Want Your Students to Be Job-Ready with 21st Century Skills? Change Pedagogies: A Pedagogical Paradigm Shift from Vygotskyian Social Constructivism to Critical Thinking, Problem Solving and Siemens' Digital Connectivism", International Journal of Higher Education, 3 (2014), 81-91

Ma'ruf, M., A. Setiawan, and A. Suhandi, "Identification of Android-Based Interactive Multimedia Needs for Basic Physics Content", AIP Conference Proceedings, 2194 (2019) 
Montrieux, Hannelore, Ruben Vanderlinde, Tammy Schellens, and Lieven De Marez, “Teaching and Learning with Mobile Technology: A Qualitative Explorative Study about the Introduction of Tablet Devices in Secondary Education", PLoS ONE, 10 (2015), 1-17

Nengrum, Thityn Ayu, Najamuddin Pettasolong, and Muhammad Nuriman,

"Kelebihan dan Kekurangan Pembelajaran Luring dan Daring dalam Pencapaian Kompetensi Dasar Kurikulum Bahasa Arab di Madrasah Ibtidaiyah 2 Kabupaten Gorontalo", Jurnal Pendidikan, 30 (2021)

Palupi, Bening Sri, Slamet Subiyantoro, Rukayah, and Triyanto, “The Effectiveness of Guided Inquiry Learning (GIL) and Problem-Based Learning (PBL) for Explanatory Writing Skill”, International Journal of Instruction, 13 (2020), 713-730

Prabowo, Tjahjo, Mohamad Suharto, Mulyanto, and Nadia Sigi Prameswari, "The Roles of Interactive Multimedia Learning Android-Based Application for Primary Schools Teachers", 3rd ISME International Colloquium, 1 (2016), 585-591

Pustika, Reza, "Future English Teachers' Perspective towards the Implementation of ELearning in Covid-19 Pandemic Era", Journal of English Language Teaching and Linguistics, 5 (2020)

Putra, Alfyananda Kurnia, Alfi Sahrina Sumarmi, Azni Fajrilia, Muhammad Naufal Islam, and Batchuluun Yembuu, "Effect of Mobile-Augmented Reality (MAR) in Digital Encyclopedia on The Complex Problem Solving and Attitudes of Undergraduate Student", International Journal of Emerging Technologies in Learning, 16 (2021), 119-34

Riyana, Cepi, “Peningakatan Kompetensi Pedagogis Guru Melalui Penerapan Model Education Centre Of Teacher Interactive Virtual (Educative)", Jurnal Penelitian Pendidikan, 11 (2011), 40-48

Rodríguez, Gemma, Nora Pérez, Gemma Núñez, Josep E. Baños, and Mar Carrió, “Developing Creative and Research Skills through an Open and Interprofessional Inquiry-Based Learning Course", BMC Medical Education, 19 (2019), 1-13

Setyowati, RR Nanik, Maya Mustika Kartika Sari, and Siti Maizul Habibah, “Improving Critical Thinking Skills of Students through the Development of Teaching Materials", Advances in Social Science, Education and Humanities Research, 226 (2020)

Silber-Varod, Vered, Yoram Eshet-Alkalai, and Nitza Geri, "Tracing Research Trends of 21st-Century Learning Skills", British Journal of Educational Technology, 50 (2019), 3099-3118

Sophia, Anggun, and Yensasnidar, “Android-Based Interactive Learning Multimedia Validity in Genetic Substance and Synthesis Protein for Students of Medical Laboratory Technology ( TLM )", International Journal of Progressive Sciences and Technologies, 2019 
Sutiani, Ani, Manihar Situmorang, and Albinus Silalahi, "Implementation of an Inquiry Learning Model with Science Literacy to Improve Student Critical Thinking Skills", International Journal of Instruction, 14 (2021), 117-138

Ulger, Kani, "The Relationship between Creative Thinking and Critical Thinking Skills of Students", Journal of Education, 31 (2016), 695-710

Wariyanti, Ari, “Pengaruh Model Pembelajaran Inkuiri Terhadap Kemampuan Berpikir Kritis dan Hasil Belajar Siswa Kelas IV SD pada Subtema Keindahan Alam Negeriku", Jurnal Review Pendidikan Dasar : Jurnal Kajian Pendidikan dan Hasil Penelitian, (2019)

Yusuf, N., and N. Al-Banawi, “The Impact of Changing Technology: The Case of ELearning", Contemporary Issues in Education Research, 6 (2013), 173-180

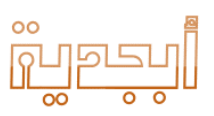

